\title{
Local Investments in Nigeria: What Role for Capital Market Operations
}

\author{
Olure-Bank Aadeyinka Michael ${ }^{1}$, Omodele Kilanko ${ }^{1}$, Gbadebo Salako ${ }^{2}$, Ajiteru Temilade ${ }^{2}$ \\ ${ }^{1}$ Department of Economics, Faculty of Social Sciences, Joseph Ayo Babalola University, Ikeji-Arakeki, Osun State, Nigeria \\ ${ }^{2}$ Department of Economics, Faculty of Arts and Social Sciences, Emmanuel Alayande College Education, Oyo, Oyo State, Nigeria
}

Email address:

Adeyinka67@gmail.com (Olure-Bank A. M.), nikeolure@yahoo.co.uk (Olure-Bank A. M.), gbadebosalako@gmail.com (G. Salako)

\section{To cite this article:}

Olure-Bank Aadeyinka Michael, Omodele Kilanko, Gbadebo Salako, Ajiteru Temilade. Local Investments in Nigeria: What Role for Capital Market Operations. Journal of Investment and Management. Vol. 4, No. 4, 2015, pp. 100-112. doi: 10.11648/j.jim.20150404.12

\begin{abstract}
There have been the growing concerns and controversies on the role of the Stock markets on economic growth and development. There have been mixed results; while some are in support of a positive link, some negative link and others do not find any empirical evidence to support such conclusion. In this study. To explored the roles or effectiveness of capital market instruments on Nigerian economic growth. Two models were formulated and data for the period 2004-2014 were collated while the Error Correction and co-integration model were employed for analysis with result of long run equilibrium. This study examines the role of the Nigerian capital market operations on the development of the Nigeria local investment in the manufacturing sector, recommendations were made for active stock market to be developed in the country.
\end{abstract}

Keywords: Stock Market, Stock Prices, Market Capitalisation, Economy, Nigerian Stock Exchange, Manufacturing, Economic Growth

\section{Introduction}

Over the years, Economists have been emphasising the need for effective mobilisation of resources as a catalyst for national development in any economy, which can only be achieved through the effectiveness in the mobilisation and allocation of funds to different sectors of the economy, so as to allow them manage their human or material resources which will result in optimal output for a sustainable growth and development in any economy. Basically, the capital market is primarily created to provide avenues for effective mobilisation of idle funds from the surplus economic unit and channel them into the deficit economic unit for longterm investment purpose. It, therefore, serves as a linkage or mechanism between the deficit sector and the surplus sector in any economy. The suppliers of funds are basically individuals and corporate bodies as government rarely supply funds to the market. The users of funds, by contrasts, consist mainly of corporate bodies and government. (Oke, 2011)

The capital market is a highly specialised and organised financial market and indeed essential agent of economic growth because of its ability to facilitate and mobilise saving and investment. To a great extent, the positive relationship between capital accumulation real economic growths has long affirmed in economic theories (--.Anyanwu, 1993).

Success in capital accumulation and mobilisation for development varies among nations, but it is largely dependent on domestic savings and inflows of foreign capital. Therefore, to arrest the menace of the current economic downturn, effort must be geared towards effective resources mobilisation. It is in realisation of this that consideration is given to measure for the development of capital market as an institution for the mobilisation of finance from the surplus sectors to the deficit sectors.

There have been the growing concerns and controversies on the role of the Stock markets on economic growth and development (Oyejide 1994; Levine and Zervos 1996; Demirgue-kunt and Levine 1996;Nyong 1997; Obadan 1998; Sule and Momoh 2009; Ewah,Esang and Bassey 2009).There have been mixed results; while some are in support of a positive link, some negative link and others do not find any empirical evidence to support such conclusion. For instance.

Atje and Jovanovic (1993) found in a cross-country study of stock and economic growth of 40 countries from 1980 to 1988 that there was a significant correlation between the average economic growth and stock market capitalisation.

Levine and Zervos (1996) examined whether there was a strong empirical relationship between stock market 
development and long-run economic growth. They found a strong correlation between overall stock market development and long-run economic growth.

Demiurgic-Kunt and Levine (1996) using data from 44 countries for the period 1986 to 1993 found that different measures of stock exchange size are strongly correlated to other indicators of activity levels of financial, banking, nonbanking institutions as well as to insurance companies and pension funds. They concluded that countries with welldeveloped stock markets tend to also have well-developed financial intermediaries.

Again, Demiurgic-Kunt and Maksimovic(1998) have shown and re-emphasised the complementary role of the stock market and banks that they were not rival or alternative institutions using 30 countries from 1980 to 1991.

Levine and Zervos (1998) used pooled cross-country time series regression of 47 countries from 1976 to 1993 to evaluate whether stock market liquidity is related to growth, capital accumulation and productivity. They towed the line of Demiurgic-Kunt and Levine (1996) by conglomerating measures such as stock market size, liquidity and integration with world market, into index of stock market development. The rate of Gross Domestic Product (GDP) per capita was regressed on a variety of variables designed to control for initial conditions, political instability, investment in human capital and macro economic condition and then, included the conglomerated index of stock market development. They found empirically that the measures of stock market liquidity were strongly related to growth, capital accumulation and productivity while stock market size does not seems to correlate to economic growth.

Nyong (1997) developed an aggregate index of capital market development and used it to determine its relationship with long-run economic growth in Nigeria. The study employed a time series data from 1970 to 1994. Four measures of capital market development-ratio of market capitalisation to GDP (in \%), ratio of total value of transactions on the main stock exchange to GDP (in \%), the value of equities transactions relative to GDP and listing were used. The four measures were combined into one overall composite index $[\mathrm{p}]===] \backslash][11$ market development using principal component analysis. The financial market depth was included as control. It was found that the capital market development is negatively and significantly correlated with the long-run growth in Nigeria.

Demiurgic-Kunt and Maksimovic (1998) cited in Henry (2000) found a relationship between economic growth and the stock market activity in the field of transmission of security (secondary market) more than in funds channeling (primary market).

Barlett (2000) demonstrated that a rising stock price raises the wealth of the economy (wealth effect ) by encouraging increase in consumers consumption and increase in investment.

Ewan et al. (2009) appraise the roles of the capital market efficiency on the economic growth of Nigeria using time series data from 1961 to 2004.They found that the capital market in Nigeria has the potential of growth inducing but it has not contributed meaningfully to the economic growth of Nigeria because of low market capitalization, low absorptive capitalization, illiquidity, misappropriation of funds among others.

Harris (1997) did not find hard evidence that stock market activity affects the level of economic growth.

\subsection{Statement of the Problem}

There is abundant evidence that most Nigerian manufacturing businesses have no access to long-term capital. The manufacturing sector has depended mainly on short-term financing such as overdrafts to finance even longterm capital. Based on the maturity matching concept, such financing is risky. All such firms need to raise an appropriate mix of short- and long-term capital.

Most recent literatures on the Nigeria capital market have recognised the tremendous performance the market has recorded in recent times. However, the vital role of the capital market in economic growth and development has been empirically investigated thereby creating a research gap in this area. This study is undertaken to examine the contribution of the capital market in the Nigerian economic growth and development. Aside the social and institutional factors inhibiting the process of economic development in Nigeria, the bottleneck created by the dearth of finance to the economy constitutes a major setback to its development. As a result, it is necessary to examine the Nigerian capital market.

\subsection{Objectives of the Study}

The main purpose of this study is to examine the activities and roles of Nigerian capital market on local investments. The specific objectives are as follows:

(i) To evaluate the roles of Capital Market on an economy;

(ii) To investigate the performance of the capital market in relation to the local investments in Nigeria economy;

(iii) To examine the operations of the Nigerian capital market.

\subsection{Significance of the Study}

The study explored the roles or effectiveness of capital market instruments on Nigerian economic growth. Though the scope of the study was limited to the capital market and manufacturing sector of the economy, it is hoped that the exploration of this market will provide a broad view of the operations of the capital market. It will contribute to existing literature on the subject matter by investigating empirically the role, which the capital market plays in the economic growth and development of the country. The main importance of this study is that it will provide policy recommendations to policy-makers on ways to improve operations and activities of the capital market.

\subsection{Scope and Delimitation of the Study}

The economy is a large component with lot of diverse and sometimes complex parts; this research work only looked at 
a particular part of the economy (the financial sector). This work did not cover all the facets that make up the financial sector, but focus only on the capital market and its activities as it roles on the Nigerian economic growth. The empirical investigation of the roles of the capital market on the economic growth in Nigeria was restricted to the period between 2004 and 2014. Secondary data was used in this study. The relevant data used were sourced from the publications of the Nigerian Stock Exchange and Central Bank of Nigeria. Some of the publications include; the Nigerian Stock Exchange Fact book, CBN's Statistical Reports, CBN's Annual Reports and Statement of Accounts for the years under review

\subsection{Outline of the Study}

The study is divided into five (5) chapters and organised as follows: Chapter one form the introduction part, this is where the main theme of the research is given. It comprises of the statement of the problem, objectives of the study, significance of the study, scope and delimitation of the study and outline of the study. Chapter two is the literature review early empirical studies, theoretical and conceptual framework of the roles of capital market on the economic growth of Nigeria. Chapter three forms the research methodology which includes sources of data, method of data analysis and model specification. Chapter four is the data analysis while chapter five includes the summary, conclusion and recommendations.

\section{Literature Review}

The stock market being a market for dealing in medium to long-term securities provides facilities for stock brokers and traders to trade stock and other securities. It is a market for where long term funds are made available by the surplus unit to the deficit unit.

According to Soyode and Oyedeji (2005), the stock market connotes ideas of surplus and also the savings that result from society income that have not been spent in procuring goods and services.

Al-Faki (2006) stated that the capital market is a network of specialised financial institutions, series of mechanism, processes and infrastructure that in various ways facilitate the bringing together of suppliers and users of medium to long-term fund (capital) for investment in socio-economic developmental projects

Osaze (2009) sees the capital market as a driver of any economy to growth and development because it is essential for long-term growth capital formation. It is crucial in the mobilisation of savings and channeling of such funds i.e. savings to profitable self- liquidating investment. Therefore, the Nigeria stock market provides the necessary lubricant that keeps turning the wheel of the economy.

Okereke (2008) states that the capital market is made up of market and institutions which facilitates the issuance and secondary trading of long-term financial instruments. Unlike the money market which functions basically to provide short term funds, the capital market provides the industries and governments long term funds to meet their long term capital requirement such as financing of fixed investment like buildings, plants, machinery, bridges, e.t.c. Therefore, the capital market plays a very active role in the stimulation of economic growth and development however, in the absence of well functioning capital market, economic growth and development would be hampered, as the money market is not designed to provide such funds. Hence, the stock market is at that core of the capital market development in any country.

\subsection{Early Empirical Studies}

Several studies have been carried out by different scholars to determine how effective the stock market is, in the growth of the economy (manufacturing sector). In a study carried out by Barlett (2000), he stated that a rising stock prices have two main-effects on the economy; first it raises wealth in the economy. This increase in wealth raises the amount of consumer spending and thereby increases the wealth of the nation. Secondly, rising stock prices can increase investment spending. We see that one way a firm can finance investment spending, is to issue stock. If stock prices rise, it can raise more money per share of the stock issued.

Irving study of 2004 considered the links between stock exchanges and overall socio- economic development to be tenuous, nonexistent or even harmful;. He advised African countries not to devote further scarce resources and efforts to promoting stock exchange, since there are many weightier problems to address in Africa; high poverty level, in adequate social services and undeveloped infrastructure. Even if the resources were available, stock market could expose already fragile developing economies to the stabilising effects of short term, speculative capital inflows.

As shown by Moore et al (2006a), stochastic policy simulations within a flow of funds mode can shed light on the type of financial reforms policies for influencing outcomes for households, companies, banks and government.

As Fleming and Giugale (2000) emphasise, a key advantage of the flow of funds is that it imposes internal consistency on analyses and forecasts, and provide an exposition of the complete financial implications of policy or other changes.

Victor (2009), states that because the financial crisis is characterised by bank fragility, it may impair (through exchange rate and stock price effects) the financial intermediation function of domestic banks in Africa in three main ways;

a. The immediate effect is a reduction in the supply of intermediary capital i.e. a credit squeeze, popularly known as a credit crunch;

b. A collapse of the prices of real assets (e.g. residential houses) and company real assets, leading to a collateral squeeze;

c. Price and other incentives for attracting deposits from household sector fall, leading to a contraction in the supply of savings i.e. a saving squeeze. He also states that the increase in banks competitiveness is matched 
by the ability of the banks to extend credit to households and companies.

Ariyo and Adelegan (2005) contend that the liberalisation of capital market led to the growth of the Nigerian capital market, yet its roles at the macro-economy was negligible. Again, the capital market was instrumental to the initial 25banks that were able to meet the minimum capital requirement of $\mathrm{N} 25$ billion during the banking sector consolidation in 2005.

Ewan et al (2009) appraise the roles of the stock market efficiency on the economic growth of Nigeria using time series data from 1961 to 2004. They found that the stock market in Nigeria has the potential of growth inducing but it has not contribution meaningfully to the economic growth of Nigeria, because of low market capitalisation, low absorptive capitalisation, illiquidity, misappropriation of funds among others.

A study by Alile in 2002 using Nigerian data provided some dissenting evidence that stock market development statistically had non significant effect on economic growth in Nigeria during the period 1980-2000. He interpreted the result to mean that the Nigerian stock market was unable to make significant contribution to rapid economic growth because of the existence of certain policies that blur the effectiveness of the vehicle or transmission mechanism through which stock market activities influence economic growth.

However, Rajni and Mahendra (2007) employed a time series data for the period 2001-2005 on specific firms and found out that seven (7) out of the sixteen (16) firms listed on Fiji's stock market is volatile. The volatility of stock returns were then regressed against the interest rates and the results showed that the interest rates changes have a significant effect on stock market volatility.

Mohammed and Salahuddin (2008) collated data for the period from 1971 to 2006 for Pakistan and employed a cointegration analysis for testing the long run relationship and ECM for short run dynamics. The findings suggest a positive relationship between efficient stock market and economic growth both in short run and long run.

\subsection{Theoretical and Conceptual Framework}

Capital market is defined as the market where medium to long terms finance can be raised. The capital market is the market for dealing (that is lending and borrowing) in long term loanable funds. Substantial academic literature and government strategies support the finance-led growth hypothesis, based on an observation first made almost a century ago by Joseph Schumpeter that financial markets significantly boost real economic growth and development.

Schumpeter asserted that finance had a positive roles on economic growth as a result of its effects on productivity growth and technological change. As early as 1989 the World Bank also endorsed the view that financial deepening matters for economic growth "by improving the productivity of investment". (Wikipedia, 2011).

Mbat (2001) described it as a forum through which long term funds are made available by the surplus to deficit economic units. It must however, be noted that although all surplus economic units have access to the capital market, not all the deficit economic units have the same easy access to it. The restriction on the part of the borrowers is meant to enforce the security of the funds provided by the lenders. In order to ensure that lenders are not subjected to undue risks the borrowers in the capital need to satisfy certain basic requirement. It has very profound implication for the socioeconomic growth and development of any nation.

Conceptual Framework of Capital Market Operations

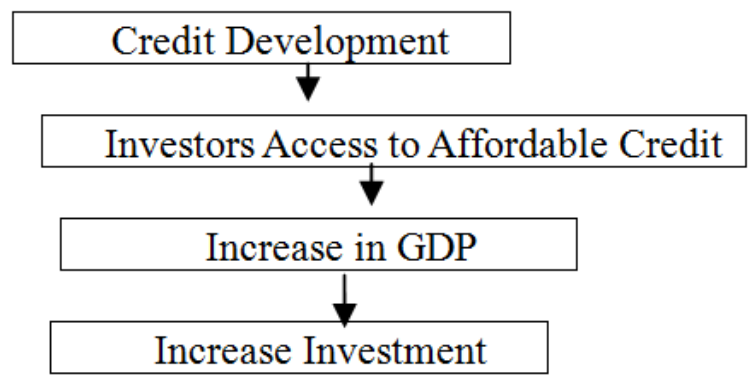

Increase Investment

Source: Author

\subsubsection{Capital Market and Economic Growth}

In principle, the capital (stock) market is expected to accelerate economic growth, by providing a boost to domestic savings and increasing the quantity and the quality of investment. The market is expected to encourage savings by providing individuals with an additional financial instrument that may better meet their risk preferences and liquidity needs. Better savings mobilisation may increase the saving rate.

The capital market also provides an avenue for growing companies to raise capital at lower cost. In addition, companies in countries with developed stock market are less dependent on bank financing, which can reduce the risk of a credit crunch. The capital market therefore is able to positively influence economic growth through encouraging savings among individuals and providing avenues for firm financing (Charles \& Charles, 2007).

Capital market offers access to a variety of financial instruments that enable economic agents to pool, price and exchange. Through assets with attractive yields liquidity and risk characteristics, it encourages savings in financial form.

This is very essential for government and other institutions in need of long term funds and for suppliers of long term funds. Companies can finance their operation by raising funds through issuing equity (ownership) or debenture/bond borrowed as securities. Equity have perpetual life while debenture /bond issues are structured to mature in periods of years varying from the medium to long-term of usually between five and twenty five years.( Mbat, 2001).

Based on the performance of capital market in accelerating economic growth, government of most nations tends to have keen interest in its performance. The concern is for sustained confidence in the market and for a strong investor's 
protection arrangement. Economic growth is generally agreed to indicate development an economy, because it transforms a country from a five percent saver to a fifteen percent saver. Thus it is argued that for capital market to contribute or roles on the economic growth in Nigeria, it must operate efficiently. Most often, where the market operate efficiently, confidence will be generated in the minds of the public and investors will be willing to part with hard earned funds and invest them in securities with the hope that in future they will recoup their investment.(Ewah et al, 2009)

The theoretical explanation on the nexus between capital market and economic growth is further explicated using Efficient Market Hypothesis (EMH) developed by Fama in 1965. According to EMH, financial markets are efficient or prices on traded assets that have already reflected all known information and therefore are unbiased because they represent the collective beliefs of all investors about future prospects. Previous test of the EMH have relied on longrange dependence of equity returns. It shows that past information has been found to be useful in improving predictive accuracy. This assertion tends to invalidate the EMH in most developing countries. Equity prices would tend to exhibit long memory or long range dependence, because of the narrowness of their market arising from immature regulatory and institutional arrangement. They noted that, where the market is highly and unreasonably speculative, investors will be discouraged from parting with their funds for fear of incurring financial losses. In situations like the one mentioned above, has detrimental effect on economic growth of any country, meaning investors will refuse to invest in financial assets. The implication is that companies cannot raise additional capital for expansion. Thus, it suffices to say that efficiency of the capital market is a necessary condition for growth in Nigeria.(Nyong, 2003).

Ariyo and Adelegan (2005) contend that, the liberalisation of capital market contributes to the growth of the Nigeria capital market, yet its roles at the macro-economy is quite negligible.

In another exposition, Gabriel (2002) as stated by Nyong (2003) lay emphasis on the Romanian capital market and conclude that the market is inefficient and hence it has not contributed to economic growth in Romanian.

Ekundayo (2002) argues that a nation requires a lot of local and foreign investments to attain sustainable economic growth and development. The capital market provides a means through which this is made possible.

Ewah, et al (2009) capital market provide the opportunities for the purchase and sale of existing securities among investors thereby encouraging the populace to invest in securities fostering economic growth.

\subsubsection{The Nigerian Security and Exchange Commission}

The Nigerian security and exchange commission (NSEC) is the apex institution for the regulation and monitoring of the Nigeria capital market. The commission was established under the security and exchange commission decree 1979, operating retrospectively from $1^{\text {st }}$ April 1978 . Prior to the
SEC, two bodies had in succession been responsible for the monitoring of capital market activities in Nigeria. The first was capital issues committee, which operated between 1962 and 1972. It could not be seen as the superintendent of the capital market because its functions were more or less advisory without the force of instruction even through its functions included the coordination of capital market activities. The next body was the capital market issues commission (CIC) which came into being in March 1973. The C.I.C, unlike its predecessor, had full powers to determine the price, timing and volume of security to be issued. Despite this wider power, the CIC could not be seen as the apex of capital market because it concerned itself with public companies alone and its activities did not cover the stock exchange and government securities.

The enabling Act of the Securities and Exchange Commission specifies its overriding objectives as investors' protection and development while its functions were divided into two regulatory and development.

The functions of the commission are extensively spelt out in Nigeria Securities and Exchange Commission Decree (Decree No 29) of 1983 and the Nigerian Enterprises Promotion Decree 1990. According to section (6) subsection (9) to (10) the commission is charged with the following duties and functions.

i Determining the amount of price and time when securities of companies are to be sold to the public whether through offer for sale or subscription.

ii Registering all securities proposed to be offered for sale to or for subscription by the public.

iii Maintaining surveillance over the securities market to ensure orderly, fair and equitable dealing in securities.

iv Protecting the integrity of the security market against any abuses arising from the practice of insider trading.

$\mathrm{v}$ Acting as regulatory apex organisation for the Nigerian capital market including the Nigerian Stock Exchange and its branches to which it would be at liberty to delegate power.

vi Creating the necessary atmosphere for the orderly growth and development of the capital market.

vii Reviewing, approving and regulating merger acquisition and all forms of business combination.

viii Registering Stock Exchange or their branches, registers investment advisers, securities dealers and their agents and controlling and supervising their activities with a view to maintaining proper standards of conduct and professionalism in the securities business.

ix Undertaking such other activities as are necessary or expedient for giving fall effect to the provisi is decree.

\subsubsection{The Nigerian Stock Exchange}

As one of the constituencies of the capital market, the exchange is a private, nonprofit making organisation, limited by guarantee. It was incorporated via the inspiration and support of businessmen and the federal government. But owned by about 300 members. The membership includes 
financial institution, stockbrokers and individual Nigerians of high integrity, who have contributed to the development of the stock market and Nigerian economy.

The Nigerian stock exchange started with the incorporation of the then Lagos stock exchange in 1960. Trading commenced on the exchange in 1961 after the enactment of the Lagos stock exchange Act of 1961, the self regulatory organisation was subsequently reorganised and renamed the Nigerian stock exchange 197, based on the report and recommendation of Pius Okigbo financial system review commission.

The stock exchange is thus an institution of capital market, which provides trading floors where all dealing members operates on every business day. The exchange now has nine (9) branches and all the branches function principally as trading floor.

Functions of Nigerian Stock Exchange

i To provide opportunities for raising new capital.

ii To promote increasing participation by the public in the private sector of the economy.

iii iTo provide appropriate machinery to facilitate further offerings of stocks and shares to the public.

iv To provide a central meeting place for members to buy and sell existing stocks and shares and for granting quotation to new ones.

$\mathrm{v}$ To reduce the risk of liquidity by facilitating the purchasing and sale of securities.( Al-faki, 2007).

\subsubsection{Economic Growth}

Economic growth means an increase in the capacity of an economy to produce goods and services, compared from one period of time to another. Economic growth is a process by which a nation wealth increases over time.

The most widely used measures of economic growth is the rate of growth in a country's total output of goods and services gauged by the gross domestic product (GDP)

Economic growth can also be refers to as the increase of per capita gross domestic product (GDP) or other measures of aggregate income, typically reported as the annual rate of change in the real GDP.

Economic growth is primarily driven by improvement in productivity, which involves producing more goods and services with the same inputs of labour, capital, energy and materials. (Wikipedia).

Economic growth enables improvements or positive changes to take place in various areas of economic activity due to the increased production of goods and services. Economic growth will inevitably lead to economic development provided the following conditions are fulfilled.

Increased production of goods and services is not frustrated by rapid increase in population size.

There is an equitable distribution of the goods and services among individuals and areas.

The increasing level of production does not lead to mass unemployment as a result of using just a few labour-saving devices. as stated by Anyanwuocha (2008).

\subsection{The Capital Market and Nigeria'S Economic Development}

Obademi O.E and Adeyanju O.D (2010) considering the needed magnitude of growth in real resources and their allocation within an economy, financial markets are germane to the quest for growth not minding the claim that sometimes asset valuation may not adequately reflect the rate of return in investment in productive capacity. The fact is that the capital market cannot be overlooked nor wished away by any nation that is serious about achieving economic growth. The failure of state directed credit to achieve economic growth makes it imperative for the capital market to take the lead.

Also the fact that bank financial investment is often not enough makes the capital market important considering the quantum of funds in dollar conversion of what is needed for development projects after the naira devaluation and the global competitiveness of foreign direct investment quest by developing countries around the world. Moreover, retained profits are no more sufficient for expansion in the face of the present information technology revolution. The situation has been further worsened with the endemic crisis in the banking industry.

The capital market thus among others help in financing the savings-investment gap both domestically and internationally as well as finance other activities that can result in economic growth. Ordinarily the need for long term finance makes the capital market relevant to our development drive. It is common knowledge that in Nigeria in the last few years as a consequence of the liberalisation, privatisation and recapitalisation policies of the government that has swept across the telecommunication, energy, manufacturing, banking and insurance sub- sector, the capital market has played enviable roles in the attainment of the objectives of the government in pushing up the growth figures and enhanced human welfare coupled with the redistribution of income and benefits within the Nigerian business environment.

Levine et al (1997), in their study on the compatibility of stock market development with financial intermediaries and economic growth posited that stock market development is positively correlated with the development of financial intermediaries and long term economic growth. In Nigeria in recent times, the bank re- capitalisation exercise was facilitated by the capital market.

Sule K.O and Momoh C.O (2009) note that there are a lot of investment opportunities available in the Nigerian Capital Market. The ultimate aim is to create wealth and improve the welfare of the average Nigerian, which automatically translates in the nation "es per capita income. Stock Exchanges play an increasingly important role, not only for channeling resources, but also for promoting reforms to modernise the financial sector legislation as is experienced in Nigeria and other emerging economies.

In a study of, Levien (1991) points out two key arguments on how stock exchanges speed up the economic growth. The first is by making property changes possible in the 
companies, whilst not affecting their productive process; the second is by offering higher possibilities of portfolio diversification to the agents. Economic growth in a modern economy is hinged on an efficient and effective financial sector that pools domestic savings and mobilises capital for productive projects. Absence of effective capital market could leave most productive projects which carry developmental agenda unexploited. Because capital market connects the monetary sector with the real sector and therefore facilitates growth in the real sector and economic development, thereby improving the quality of lives of the citizenry.

The stakeholders, who also advocated stick and carrot measure as a solution to the growing infraction in the nation's capital market, identified the fundamental channels through which capital market is connected to economic growth and development as follows:

(1) Capital market increases the proportion of long-term savings (pensions, funeral covers, etc) that is channeled to long-term investment. Capital market enables contractual savings industry (pension and provident funds, insurance companies, medical aid schemes, collective investment schemes, etc) to mobilise long-term savings from small individual household and channel them into long-term investments.

(2) Capital market also provides equity capital and infrastructure development capital that has strong socio- economic benefits through development of roads, water and sewer systems, housing, energy, telecommunications, public transport, etc.

(3) Moreover, capital market promotes public-private sector partnerships to encourage participation of private sector in productive investments. The need to shift economic development from public to private sector to enhance economic productivity has become inevitable as resources continue to diminish. It assists the public sector to close resource gap, and complement its effort in financing essential socioeconomic development, through raising long-term project based capital.

(4) It also attracts foreign portfolio investors who are critical in supplementing the domestic savings levels. It facilitates inflows of foreign financial resources into the domestic economy.

According to Donwa P. and Odia J.,(2010) in Alile (1984) the capital market has been identified as an institution that contributes to the socio-economic growth and development of emerging and developed economies. This is made possible through some of the vital roles played such as channeling resources, promoting reforms to modernise the financial sectors, financial intermediation capacity to link deficit to the surplus sector of the economy,and a veritable tool in the mobilisation and allocation of savings among competitive uses which are critical to the growth and efficiency of the economy. It helps to channel capital or long-term resources to firms with relatively high and increasing productivity thus enhancing economic expansion and growth (Alile 1997).

Ekundayo (2002) argues that a nation requires a lot of local and foreign investments to attain sustainable economic growth and development and the capital market provides a means through which this is made possible. However, the paucity of long-term capital has posed the greatest predicament to economic development in most African countries including Nigeria.

Osaze (2000) sees the capital market as the driver of any economy to growth and development because it is essential for the long term growth capital formation. It is crucial in the mobilisation of savings and channeling of such savings to profitable self-liquidating investment.

The Nigerian capital market provides the necessary lubricant that keeps turning the wheel of the economy. It not only provides the funds required for investment but also efficiently allocates these funds to projects of best returns to fund owners. This allocative function is critical in determining the overall growth of the economy. The functioning of the capital market affects liquidity, acquisition of information about firms, risk diversification, savings mobilisation and corporate control (Anyanwu 1998).

Therefore, by altering the quality of these services, the functioning of stock markets can alter the rate of economic growth (Equakun 2005).

Okereke-Onyiuke (2000) posits that the cheap source of funds from the capital market remain a critical element in the sustainable development of the economy. She enumerated the advantages of capital market financing to include no short repayment period as funds are held for medium and long term period or in perpetuity, funds to state and local government without pressures and ample time to repay loans.

Again the capital market was instrumental to the initial 25 banks that were able to meet the minimum capital requirement of N25billion during the banking sector consolidation in 2005.The stock market has helped government and corporate entities to raise long term capital for financing new projects,and expanding and modernising industrial / commercial concerns (Nwankwo 1991).

\subsection{Roles of the Capital Market}

According to Al-Faki (2006), the capital market is a "network of specialised financial institutions, series of mechanisms, processes and infrastructure that, in various ways, facilitate the bringing together of suppliers and users of medium to long term capital for investment in socioeconomic developmental projects". The capital market is divided into the primary and the secondary market. The primary market or the new issues market provides the avenue through which government and corporate bodies raise fresh funds through the issuance of securities which is subscribed to by the general public or a selected group of investors. The secondary market provides an avenue for sale and purchase of existing securities.

Sule and Momoh (2009) found that the secondary market activities have impacted more on Nigeria per capita income by tending to grow stock market earnings through wealth 
than the primary market.

The roles of the capital market in the development of the economy include:

(1) It provides opportunities for companies to borrow funds needed for long-term investment purposes.

(2) It provides avenue for the marketing of shares and other securities in order to raise fresh funds for expansion of operations leading to increase in output/production.

(3) It provides a means of allocating the nations real and financial resources between various industries and companies. Through the capital formation and allocation mechanism the capital market ensures an efficient and effective distribution of the scarce resources for the optimal benefit to the economy.

(4) It reduces the over reliance of the corporate sector on short term financing for long term projects and also provides opportunities for government to finance projects aimed at providing essential amenities for socioeconomic development.

(5) The capital market can aid the government in its privatisation programme by offering her shares in the public enterprises to members of the public through the stock exchange.

(6) The capital market also encourages the inflow of foreign capital when foreign companies or investors invest in domestic securities, provides needed seed money for creative capital development and acts as a reliable medium for broadening the ownership base of family-owned and dominated firms.

\subsection{Contribution of the Capital Market to Socio-Economic Development of Nigeria}

The capital market is very vital to the growth, development and strength of any country because it supports government and corporate initiatives, finances the exploitation of new ideas and facilitates the management of financial risk. The rate of economic growth has been inexorably linked to the sophistication of the financial market and capital market efficiency. Both markets facilitate the mobilisation and channeling of funds into productive constituents and ensuring that the funds are used for the pursuit of socioeconomic growth and development without being idle (Akinbohungbe1996; Adebiyi 2005)

From 1961, the Nigerian capital market has growth tremendously, particularly during the periods of the indigenisation decrees of 1972 and 1977. The securities increased from 8 in 1961 to about 301 in 2008. Over the years, the Nigerian capital market has witnessed relatively stability and also recorded impressive growth. This has positioned it to positively roles the economy. There is clear evidence that the capital market remained an important source of capital for the nation's economic development in financing infrastructural projects, the privatisation programme of the government and banking sector recapitalisation in Nigeria.

Sule and Momoh (2009) conclude that the recent consolidation exercise of major financial institutions and privatisation exercise of most publicly owned enterprises are key indications of government faith in the capital market to drive growth of the Nigerian economy.

\subsection{Capital Market Provides Avenue for FDI for Economic Growth in Nigeria}

There is a growing body of empirical literature considering FDI inflows as a catalyst of economic growth. FDI provide host countries with much needed capital, technology; expertise and new managerial skills topped with some access to international export markets.

Chen et al. (1995) report that FDI inflows are positively correlated with post-1978 economic growth in China by contributing to capital formation, export earnings, and bringing about advanced managerial skills.

Blomstrom et al. (1992) finds similar evidence using a panel data from 78 developing countries where technological upgrading and knowledge spillovers are the vehicle through which FDI stimulates growth. Hence the Nigerian capital market provides avenue for FDI in the country for economic growth.

\section{Methodology}

The secondary data (Bi-annual) and a time series analysis for the period of 2004-2014, which were obtained from sources like the Nigeria stock exchange Annual report, Central Bank of Nigeria Statistical Bulletin. In order to determine the robustness of the independent partial correlation between Nigeria Capital Market operations to the growth of the economy at large, two models were employed, applying co-integration and error correction model to the data obtained. Thus, we use the gross domestic product as a proxy for growth, which is our dependent variable and stock price, market capitalisation number of deals, which are the independent variables.

For the purpose of this study, certain modification is made to model as put forward by Oke (2011). Adopted from Sule and Momoh (2009) who based their model on Demirguckunt and Maksimovic (1998) theory of non classical which was modified to measure the roles of stock market on economic growth

$$
\mathrm{PCI}=\beta 0+\beta 1 \mathrm{mc}+\beta 2 \mathrm{PER}+\beta 3 \mathrm{NLS}+\mu
$$

Where;

$\mathrm{PCI}=$ Per capita income

$\mathrm{mc}=$ Market capitalization

NLS $=$ No of listed Securities

PER $=$ Price Earring Ratio, DY-dividend Yields

The basic variables employed for this study are market capitalisation which denotes the size of the market, stock prices, number of deals which are the independent variable and the Gross Domestic Product which is the dependent variable.

Model 1 


$$
\text { GDP }(\text { maf })=\text { F }(\text { MKTCAP, NOD, SKP, } \mu)
$$

It should be noted that GDP is a proxy for economic growth. For this model, GDP relating to the manufacturing sector will be employed

Where; GDP $($ maf $)=$ Gross Domestic product,

MKTCAP $=$ Market capitalisation,

$\mathrm{SKP}=$ Stock Price,

NOD $=$ Number of Dealings,

$\mu=$ Stochastic variable (Error term)

$$
\mathrm{GDP}(\mathrm{maf})=\beta 0+\beta 1 \mathrm{MCAP}+\beta 2 \mathrm{NOD}+\beta 3 \mathrm{SP}+\mu
$$

Transforming equation (v) into natural logarithm form, we have

$\log \mathrm{GDP}(\mathrm{maf})=\log \beta_{0}+\log \beta 1 \mathrm{MCAP}+\beta_{2} \mathrm{NOD}+\log \beta_{3} \mathrm{~S}$

Model 2

$$
\mathrm{GDP}=\mathrm{f}(\text { MRTCAP, SKP, NOD, } \mu)
$$

GDP is a proxy for economic growth

Where GDP $=$ Gross Domestic Product

Econometric Function

$$
\mathrm{GDP}=\beta_{0}+\beta_{1} \mathrm{MRTCAP}+\beta_{2} \mathrm{SKP}+\beta_{3} \mathrm{NOD}+\mu
$$

Transforming equation (iii) into natural logarithm, we have

$$
\begin{array}{r}
\log \mathrm{GDP}=\log \beta 0+\log \beta 1 \mathrm{MRTCAP}+\log \beta 2 \mathrm{SKP}+ \\
\log \beta 3 \mathrm{NOD}+\mu
\end{array}
$$

Where $\beta 0$, is constant and it is the intercept of the econometric function. $\beta_{1}, \beta_{2}, \beta_{3}$, are parameters that show the relationship between the dependent and the independent variable.

\section{Result of Finding}

The results obtained from the analyses of the two analyses are presented and discussed below

Table I. Interpretation of OLS Result for Model 1 and 2.

\begin{tabular}{lllll}
\hline $\begin{array}{l}\text { Dependent } \\
\text { variable }\end{array}$ & \multicolumn{2}{l}{ Independent variable } & & \\
\hline \multirow{3}{*}{$\operatorname{GDP}_{(\mathrm{maf})}$} & Constant & SKP & MRTCAP & NOD \\
& 4.693263 & 0.581171 & 0.532133 & -0.211234 \\
$\mathrm{GDP}$ & $(1.951916)$ & $(2.65744)$ & $(2.657342)$ & $(-0.945112)$ \\
& 5.673127 & 0.351774 & 0.531779 & -0.211606 \\
& $(3.134203)$ & $(2.510005)$ & $(3.561249)$ & $(-0.911328)$ \\
\hline
\end{tabular}

Note: the t-statistics is given in parenthesis

Table II. Summary of Results.

\begin{tabular}{llllll}
\hline & R & $\mathbf{R}^{2}$ & Adj R $^{2}$ & Fc & $\begin{array}{l}\text { Durbin } \\
\text { Watson } \\
\text { Stat. }\end{array}$ \\
\hline Model 1 & 0.97 & 0.9568 & 0.9266 & 76.20794 & 1.368372 \\
Model 2 & 0.98 & 0.9767 & 0.9612 & 118.2757 & 1.281065 \\
\hline
\end{tabular}

The tabular presentation of OLS result for model 1 and 2 can also be given in equation form. As it is written below, Model 1

$$
\begin{gathered}
\mathrm{GDP}_{\mathrm{maf}}=3.691363+0.490071(\mathrm{SKP}){ }^{+} \\
0.492988(\mathrm{MRTCAP})-0.199998(\mathrm{NOD})
\end{gathered}
$$

\section{Model 2}

$$
\begin{gathered}
\mathrm{GDP}=4.524127+0.331674(\mathrm{SKP})+0.5331779(\mathrm{MRTCAP})- \\
0.168506(\mathrm{NOD})
\end{gathered}
$$

The above result shows that from both models a positive relationship exists between stock price, market capitalisation and GDP (maf) and GDP, while a negative relationship exists between number of deals and GDP (maf) and GDP. The constant parameter also shows a positive relationship to the dependent variables (GDP and GDP maf) in both models. This means that if all the explanatory variables are held constant, GDP (maf) will increase by 3.691363 and GDP will increase by 4.524127 . The value of correlation co-efficient (r), in both model with a value of $95 \%$ in model 1 and $97 \%$ in model 2, shows that a strong positive relationship exist among the variables in both models. The coefficient of determination $\left(\mathrm{r}^{2}\right)$ in both model, with a values of 0.9308 in model 1 and 0.9577 in model 2 , shows that $93.08 \%$ variation or change in GDP (maf) and $95.77 \%$ change in GDP can be explained by the explanatory variable (SKP, MRTCAP, NOD) which the remaining $6.92 \%$ and $4.23 \%$ in both models is being handled by the stochastic error term in both models.

\section{Unit Root Test}

Table III. ADF Unit Root test at level.

\begin{tabular}{lllll}
\hline Variable & $\begin{array}{l}\text { ADF test } \\
\text { stat. }\end{array}$ & $\begin{array}{l}\text { Mackinnon } \\
\mathbf{5 \%} \text { critical } \\
\text { values }\end{array}$ & $\begin{array}{l}\text { Order of } \\
\text { stationarity }\end{array}$ & Remark \\
\hline GDP $_{(\text {maf })}$ & -1.694656 & -3.1294 & $1(0)$ & $\begin{array}{l}\text { Not } \\
\text { stationary }\end{array}$ \\
GDP & -1.844934 & -3.1294 & $1(0)$ & $\begin{array}{l}\text { Not } \\
\text { stationary }\end{array}$ \\
SKP & -2.597975 & -3.1294 & $1(0)$ & $\begin{array}{l}\text { Not } \\
\text { stationary } \\
\text { MRTCAP }\end{array}$ \\
NOD & -1.891135 & -3.1294 & $1(0)$ & $\begin{array}{l}\text { Not } \\
\text { stationary } \\
\text { Not }\end{array}$ \\
ECM(Model1) & -3.444869 & -3.1294 & $1(0)$ & $\begin{array}{l}\text { Not } \\
\text { stationary } \\
\text { stationary }\end{array}$ \\
ECM(Mode2) & -3.724015 & -3.1294 & $1(0)$ & $\begin{array}{l}\text { Not } \\
\text { stationary }\end{array}$ \\
\hline
\end{tabular}

Stationary

The table above shows that the Mackinnon critical values at $5 \%$ are all greater than the ADF test, for all the variables in both models. This implies that they are not stationary. The ECM for both model are stationary. Therefore there is need to carry out test at 1 st difference to see if the variables will be stationary. 
Table IV. ADF Unit Root Test at First Difference.

\begin{tabular}{|c|c|c|c|c|}
\hline Variable & $\begin{array}{l}\text { ADF test } \\
\text { stat. }\end{array}$ & $\begin{array}{l}\text { Mackinnon } \\
5 \% \text { critical } \\
\text { values }\end{array}$ & $\begin{array}{l}\text { Order of } \\
\text { stationarity }\end{array}$ & Remark \\
\hline $\mathrm{GDP}_{(\mathrm{maf})}$ & -3.520168 & -3.1400 & $1(1)$ & stationary \\
\hline GDP & -3.092087 & -3.1400 & $1(1)$ & stationary \\
\hline SKP & -2.943547 & -3.1400 & $1(1)$ & $\begin{array}{l}\text { Not } \\
\text { stationary }\end{array}$ \\
\hline MRTCAP & -1.729862 & -3.1400 & $1(1)$ & $\begin{array}{l}\text { Not } \\
\text { stationary }\end{array}$ \\
\hline NOD & -1.659699 & -3.1400 & $1(1)$ & $\begin{array}{l}\text { Not } \\
\text { stationary }\end{array}$ \\
\hline
\end{tabular}

The above table shows that the dependent variable of model 1 (GDP(maf) and that of model 2 (GDP) are stationary at first difference because their respective ADF statistical value are greater than Mackinnon critical value at 5\%. However the independent variables (SKP, MKTCAP, NOD) are not stationary at 1 st difference, therefore we proceed to 2nd difference to test their stationary.

Table V. ADF Unit Root Test at Second Difference.

\begin{tabular}{lllll}
\hline Variable & $\begin{array}{l}\text { ADF test } \\
\text { stat. }\end{array}$ & $\begin{array}{l}\text { Mackinnon } \\
\mathbf{5 \%} \text { critical } \\
\text { values }\end{array}$ & $\begin{array}{l}\text { Order of } \\
\text { stationarity }\end{array}$ & Remark \\
\hline SKP & -3.772758 & -3.0521 & $1(2)$ & $\begin{array}{l}\text { stationary } \\
\text { MRTCAP }\end{array}$ \\
NOD & -2.118995 & -3.0521 & $1(2)$ & $\begin{array}{l}\text { Not } \\
\text { stationary }\end{array}$ \\
& -2.836922 & -3.0521 & $1(2)$ & $\begin{array}{l}\text { Not } \\
\text { stationary }\end{array}$ \\
\hline
\end{tabular}

The above shows that SKP is stationary at $2^{\text {nd }}$ difference while MRTCAD and NOD are not stationary. The test for stationary is being done at absolute term of the value.

Table VI. Summary of Stationary.

\begin{tabular}{ll}
\hline Variables & Order of stationarity \\
\hline $\mathrm{GDP}_{(\text {maf }}$ & $1(1)$ \\
GDP & $1(1)$ \\
SKP & $1(2)$ \\
MRTCAP & - \\
NOD & - \\
ECM(Model 1) & $1(0)$ \\
ECM(Model 2) & $1(0)$ \\
\hline
\end{tabular}

The table above shows that GDP (maf) and GDP are stationary at 1 st difference, ECM is stationary at level while SKP is stationary at $2^{\text {nd }}$ difference. However, NOD and MRTCAP are not stationary but will be used because of their importance in explaining the Nigerian Stock Market.

Co-Integration Test

The co-integration test is performed using Johansen likelihood estimation equation, which is done to test whether a long-run relationship exist among the variables. If it shows that at least one co-integrating equation exist among variables under investigation, then a long run equilibrium relationship exist among them. The table below shows the summary of Johansen co integration tests conducted on the two models.

Model 1
Table VII. Result of Johansen Co-integration Test.

\begin{tabular}{llllc}
\hline Eigen value & $\begin{array}{l}\text { Likelihood } \\
\text { ratio }\end{array}$ & $\begin{array}{l}\mathbf{5 \%} \text { critical } \\
\text { values }\end{array}$ & $\begin{array}{l}\mathbf{1 \%} \text { critical } \\
\text { value }\end{array}$ & $\begin{array}{l}\text { Hypothesised } \\
\text { no of CE 1 }\end{array}$ \\
\hline 0.811759 & 69.48779 & 47.21 & 54.46 & None** \\
0.687393 & 37.75716 & 29.68 & 35.65 & At most1** \\
0.534647 & 15.66379 & 15.41 & 20.04 & At most $2^{* *}$ \\
0.057719 & 1.129577 & 3.76 & 6.65 & At most 3** \\
\hline
\end{tabular}

The co-integration equation is specified below

GDP $\quad(\mathrm{maf})=6.499705-0.741436$ SKP -1.741329 MRTCAP + 1.997290 NOD

(0.10616) (0.242559) (0.33466)

The above result shows that there exist a long run relationship among the variables in the model as the likelihood ratio of 69.48779 is greater than the $5 \%$ critical value of 47.21 at the None hypothesized (None**). The cointegration equations shows that there exist a positive relationship between the constant parameter, NOD and GDP (maf), while a negative relationship exist between SKP, MRTCAP and GDP(maf).

\section{Model 2}

TableVIII. Result of Johansen Co-integration Test.

\begin{tabular}{llllc}
\hline Eigen value & $\begin{array}{l}\text { Likelihood } \\
\text { ratio }\end{array}$ & $\begin{array}{l}\mathbf{5 \%} \text { critical } \\
\text { values }\end{array}$ & $\begin{array}{l}\mathbf{1 \%} \text { critical } \\
\text { value }\end{array}$ & $\begin{array}{l}\text { Hypothesised } \\
\text { no of CE 1 }\end{array}$ \\
\hline 0.788262 & 60.84838 & 47.21 & 54.46 & None** \\
0.636259 & 31.35271 & 29.68 & 35.65 & At most ${ }^{*}$ \\
0.429507 & 12.13778 & 15.41 & 20.04 & At most 2 \\
0.074643 & 12.13778 & 3.76 & 6.65 & At most 3 \\
\hline
\end{tabular}

The co integration equation is

GDP $=6.185605-0.148026$ SKP- 1.948884 MRTCAP + $2.041826 \mathrm{NOD}$

$$
(0.16114)(0.48690)(0.62841)
$$

This shows that there exist a long-run equilibrium relationship among the variables in the model because the likelihood ratio of 60.84838 is greater than the $5 \%$ critical value of 47.21 at none hypothesis (None**). The co integration equation shows that there exist positive relationships between the constant parameter; NOD and GDP while a negative relationship exist between SKP, MRTCAP and GDP.

Error Correction Model

The table below shows the over parameterised and parsimonious ECM for model 1 and 2

Model 1

Table IX. Over-parameterised ECM.

\begin{tabular}{lllll}
\hline Variables & $\begin{array}{l}\text { Co- } \\
\text { efficient }\end{array}$ & $\begin{array}{l}\text { Standard } \\
\text { Error }\end{array}$ & T-Stat. & Probability \\
\hline $\mathrm{D}_{\left(\mathrm{GDP}_{(-1,2)}\right.}$ & -0.506561 & 0.137642 & -3.680283 & 0.0042 \\
$\mathrm{D}\left(\mathrm{SKP}_{, 2)}\right.$ & 0.402089 & 0.239541 & 1.678583 & 0.1242 \\
$\mathrm{D}\left(\mathrm{SKP}_{(-1), 2)}\right.$ & 0.108638 & 0.223768 & 0.485492 & 0.6378 \\
$\mathrm{D}_{\left(\mathrm{MRTCAP}_{, 2)}\right.}$ & 0.392128 & 0.762336 & -0.514377 & 0.6182 \\
$\mathrm{D}_{\left(\mathrm{MRTCAP}_{(-1), 2)}\right.}$ & 0.258521 & 0.453328 & 0.570274 & 0.5811 \\
$\left.\mathrm{D}_{(\mathrm{NOD}}, 2\right)$ & 0.388149 & 0.480070 & 0.808525 & 0.4376 \\
$\left.\mathrm{D}_{(\mathrm{NOD}}(-1), 2\right)$ & 0.205328 & 0.415713 & 0.493919 & 0.6320 \\
$\mathrm{ECM}_{(-1)}$ & -1.116356 & 0.232369 & -4.804233 & 0.0007 \\
\hline
\end{tabular}

$\mathrm{R}^{2}=0.865637$

Adjusted $\mathrm{R}=0.771582$

Durbin Watson stat. $=2.2954$ 
Table X. Parsimonious ECM.

\begin{tabular}{lllll}
\hline Variables & $\begin{array}{l}\text { Co- } \\
\text { efficient }\end{array}$ & $\begin{array}{l}\text { Standard } \\
\text { Error }\end{array}$ & $\begin{array}{l}\text { T- } \\
\text { statistics }\end{array}$ & Probability \\
\hline D(SKP,2) & 0.062664 & 0.548688 & 0.114207 & 0.9107 \\
D(MRT.CAP(-1),2) & -0.751005 & 0.930960 & -0.806699 & 0.4333 \\
D(NOD,2) & 0.216827 & 0.453964 & 0.279376 & 0.7840 \\
ECM(-1) & 0.681760 & 0.519725 & 1.311771 & 0.2107 \\
\hline
\end{tabular}

$\mathrm{R}^{2}=0.146389$

Adjusted R $=-0.036528$

Durbin-Watson stat. $=2.592435$

The negativity of the ECM in the over parameterised ECM is in conformity with our a-priori expectation. This implies that the present value of GDPmaf adjusts rapidly to changes in SKP, MRTCAP and NOD. The large values of ECM given as $111.6 \%$ show a feedback of that value from the previous period disequilibrium of the present level of GDP maf in the determination of the causality between the past level of GDPmaf and the present and past level of SKP, MRTCAP and NOD. The coefficient of determination $\left(\mathrm{R}^{2}\right)$ shows that about $86.56 \%$ variation in the dependent variable (GDP $\mathrm{maf}$ ) can be explained by the explanatory variable (SKP, MRTCAD, NOD) while the remaining $13.44 \%$ is handled by the stochastic error term.

The coefficient of SKP and NOD in the parsimonious ECM is also in confirmedly with that of the over parameterised ECM as they are positively related to $\mathrm{GDP}_{\text {maf. }}$ While MRTCAP in the parsimonious model is also conformity with that of the over parameterised model as it is negatively related to $\mathrm{GDP}_{\mathrm{maf}}$

Model 2

Table XI. Over-parameterised ECM.

\begin{tabular}{lllll}
\hline Variables & $\begin{array}{l}\text { Co- } \\
\text { efficient }\end{array}$ & $\begin{array}{l}\text { Standard } \\
\text { Error }\end{array}$ & T-Stat. & Probability \\
\hline $\mathrm{D}\left(\mathrm{GDP}_{(-1,2)}\right.$ & -0.595508 & 0.162618 & -3.662002 & 0.0044 \\
$\mathrm{D}\left(\mathrm{SKP}_{, 2)}\right.$ & 0.182248 & 0.175562 & 1,038084 & 0.3237 \\
$\mathrm{D}\left(\mathrm{SKP}_{(-1), 2)}\right.$ & 0.058999 & 0.143188 & 0.412039 & 0.6890 \\
$\left.\mathrm{D}_{(\mathrm{MRTCAP}}, 2\right)$ & 0.036420 & 0.481457 & 0.075646 & 0.9412 \\
$\mathrm{D}_{(\mathrm{MRTCAP}}$ & 0.156351 & 0.314060 & 0.497838 & 0.6294 \\
$\mathrm{D}_{(-1), 2)}$ & 0.102104 & 0.316790 & 0.322308 & 0.7539 \\
$\left.\mathrm{D}_{(\mathrm{NOD}}(-1), 2\right)$ & 0.056150 & 0.267861 & 0.209623 & 0.8382 \\
$\mathrm{ECM}_{(-1)}$ & -0.933259 & 0.297798 & -3.133867 & 0.0106 \\
\hline
\end{tabular}

$\mathrm{R}^{2}=0.793857$

Adjusted $\mathrm{R}=0.649556$

Durbin-Watson stat $=1.852616$.

Table XII. Parsimonious ECM.

\begin{tabular}{lllll}
\hline Variables & Co-efficient & Standard Error & T-statistics & Probability \\
\hline D(SKP,2) & -0.261087 & 0.246212 & -1.060416 & 0.3069 \\
D(MRT.CAP(- & -0.0887867 & 0.295422 & -0.297417 & 0.7705 \\
1),2) & & & -209919 & 0.6953 \\
D(NOD,2) & -0.081239 & 0.203139 & -0.399919 \\
ECM(-1) & 0.570433 & 0.504981 & 1.129612 & 0.2776 \\
\hline
\end{tabular}

$\mathrm{R}^{2}=0.108645$

Adjusted $\mathrm{R}=-0.082359$

Durbin-Watson stat $=3.059611$

The negative sign of ECM in over parameterised ECM is in conformity with our a-priority expectation. This implies that the present value of GDP adjust rapidly to changes in SKP, MRTCAP, NOD. The large value of ECM given as $93.32 \%$ shows a feedback of that value from the previous period disequilibrium of the present level from the previous period disequilibrium of the present level of GDP in the determination of the causality between the past level of GDP and the present and past level of SKP, MRTCAP and NOD. The coefficient of determination $\left(\mathrm{R}^{2}\right)$ shows that about $79.4 \%$ variation in the dependent variable (GDP) can be explained by the explanatory variable (SKP, MRTCAP and NOD) while the remaining $20.6 \%$ is left to the stochastic error term to handle.

The coefficient of SKP, MRTCAP and NOD in the parsimonious ECM is negatively related to GDP.

Model 1

Table XIII. Standard error test result.

\begin{tabular}{lllllll}
\hline Variable & $\begin{array}{l}\text { Co- } \\
\text { efficient }\end{array}$ & $\begin{array}{l}\text { Co- } \\
\text { efficient/2 }\end{array}$ & $\begin{array}{l}\text { Standard } \\
\text { Error }\end{array}$ & H$_{\mathbf{0}}$ & $\mathbf{H}_{\mathbf{1}}$ & Remark \\
SKP & 0.402089 & 0.2010445 & 0.239541 & Accept & Reject & Insignificant \\
MRTCAP & - & -0.196064 & 0.762336 & Accept & Reject & Insignificant \\
NOD & 0.392128 & & & & & \\
\hline
\end{tabular}

Model 2

Table XIV. Standard error test result.

\begin{tabular}{lllllll}
\hline Variable & $\begin{array}{l}\text { Co- } \\
\text { efficient }\end{array}$ & $\begin{array}{l}\text { Co- } \\
\text { efficient/2 } 2\end{array}$ & $\begin{array}{l}\text { Standard } \\
\text { Error }\end{array}$ & $\mathbf{H}_{\mathbf{0}}$ & $\mathbf{H}_{\mathbf{1}}$ & Remark \\
\hline SKP & - & - & & & & \\
& 0.261087 & 0.1305435 & 0.246212 & Accept & Reject & Insignificant \\
MRTCAP & - & - & & & & \\
& 0.087867 & 0.0439335 & 0.295433 & Accept & Reject & Insignificant \\
\multirow{2}{*}{ NOD } & - & - & & & & \\
& 0.081239 & 0.0406195 & 0.203139 & Accept & Reject & Insignificant \\
\hline
\end{tabular}

Decision Rule

If Coefficient $>$ standard Error - Significant $\left(\right.$ Reject $\mathrm{H}_{0}$ and Accept H1) 2

If Coefficient $<$ standard Error - Insignificant (Accept $\mathrm{H}_{0}$ and Reject H1)

The standard error test above shows that the parameters are insignificant in the explanation of the long-run as the standard error statistics are greater than the coefficients of the parameter divided by 2 in both models.

However, the F-test shows that the models are significant in the short and long run as they have F-statistics of 128.2757 in model 1 and 76. 20794 in model 2, which is greater than the f-calculated 3.20

\section{Summary of Findings}

The study examined the role of capital market on economic development of Nigeria between 2004 to 2014 . Having run the OLS and the co integration techniques to test for the short and long-run relationship in both models, it was revealed that the one sector that drives the Nigeria economy in terms of revenue is the manufacturing sector. This was revealed in the short run as an increase in stock prices of 
manufacturing firms in Nigeria contributes immensely to the share of manufacturing sector to GDP. The long run test revealed that there exists a long run equilibrium relationship among the variable in the models as the counteraction in both model is in deviation from the short run equation but it also justifies the fact that the manufacturing sector contributes majorly to the economic growth of Nigeria.

The short run relationship reveals that stock price and market capitalisation contributes positively to the share of manufacturing to GDP and the GDP as a whole, while the long run equation move in opposite direction that stock price and market capitalisation negatively affect GDP maf and GDP as a whole.

With the regression result confirms that there exists positive relationship between the capital market and economic growth. The relationship is statistically significance. This is in essence means that the roles of the capital market on economic growth is strong and significant.

i) Another major outcome of the study is that a unit increase in total listing of equity and government stock (TLS) result in an increase in GDP. The implication of this is that the economy responds favourable to measures taken to increase TLS in Nigeria Stock Exchange.

ii) The positive result of the total listing of equity and government stock implies that funds raised by the industries and governments in the capital market are spent on productive sector which enhance economic growth.

iii) The result of the value of transaction in the capital market means that the simplicity in buying and selling of securities has potential to influence economic growth positively.

These findings agree with Ewang, et al (2009) who found that capital market in Nigeria has potentials for growth inducing but has not contributed meaningfully to the economic growth of Nigeria due to low market capitalisation etc.

\subsection{Conclusion}

The study reveals that the capital market roles on economic growth via market capitalisation, value of transaction and total listing of equity and government stock. As it was observed market capitalisation, government stock and value of transaction are important capital market variables that are capable of influencing economic growth. Hence the capital market remain one of the mainstream in every economy that has the power to influence or roles economic growth therefore the organised private sector is to invest in it. The market capitalisation have not roles significantly on the GDP while volume of transaction and total listed equities and Government stock have significant roles on the GDP. The government is therefore advised to put up measures to stem up investors' confidence and activities in the market and more foreign investors should be encouraged to participate in the market for improvement in the declining market capitalisation so that it could contribute significantly to the Nigerian economic growth.

\subsection{Policy Recommendations}

In order for the Nigeria capital market to be pivotal force in Nigeria economic growth and development, the following suggestion or recommendation are put forward.

i) First improvement in the declining market capitalisation by encouraging more foreign investors to participate in the market, maintain state of the art technology like automated trading and settlement practice, electronic fund clearance and eliminate physical transfer of shares.

ii) There is also need to restore confidence to the market by regulatory authorities through ensuring transparency and fair trading transaction and dealing in the stock exchange. It must also address the reported case of abuse and sharp practices by some companies in the market.

iii) Since the total listing is significant at $1 \%$ level of significance but still far cry compare to other exchange like South African and Egypt. Therefore, these should be increase in the total member listed companies to ensure stable macroeconomic environment in order to encourage foreign multinational companies (MNCs) or their subsidiaries to be listed on the Nigerian stock exchange, relax the listing requirements to the first tier market and ensure tax rationalisation in the capital market to encourage quotation and public interest in shareholdings.

iv) Lastly, to boost the value of transactions in the Nigerian capital market, there is need for availability of more investment instruments such as derivatives, convertibles, future, and swaps options in the market.

v) Given the present political dispensation, all the tiers of government should be encourage to fund their realistic developmental programme through the capital market. This will served as a leeway to freeing the resources that may be used in other sphere of the economy.

\section{References}

[1] Owolabi A and Ajayi N.O. (2013) Asian Economic and Financial Review, 2013, 3(1):99-110

[2] Atoyebi Kehinde.O. et al (2013) Capital Market and Economic Growth in Nigeria an Empirical Analysis. Journal of Humanities And Social Science, Volume 6, Issue 6 (Jan. Feb. 2013), PP 60-68

[3] Olawoye (2011) Roles Of Capital Market On Economic Growth Of Nigeria

[4] Al-Faki M. (2006). ' The Nigerian capital market socioeconomic development". Paper Presented at the $4^{\text {th }}$ distinguished faculty of social science public lecture. University of Benin, 26 July, 9-16.

[5] Alile HI (2002). ' Establishing a stock market - the Nigerian experience". Paper presented at the conference on promoting and development capital market in Africa. Abuja No 11-13. 
[6] Ariyo and Adelegan O (2005). "Assessing the roles of Capital Market Reforms in Nigerian; An incremental approach ; paper presented at the $46^{\text {th }}$ Annual conference of the Nigerian economic society in Lagos in August 2005.

[7] Barlett, B. (2000)". Opinion Editorial on the effect of stock market on the Economy", National Centre for Policy Analysis, Feb 2000.

[8] Beck, T. Demirguc-kunt and Levine (2004). 'Stock Market, Banks and Growth Correlation or Causality?", Policy research working paper. 2000 Washington DC; World Bank.

[9] Ewang S.E, Esang AE, Bassey JU (2009),' Appraisals of Capital Market Efficiency on Economic Growth in Nigeria," International journal of business and management, December. 219-225.

[10] Demirguc-Kunt, A and Maksimovic, V (1998), "'Stock Market Development and Financial Choices of firms", World Bank Economic Review, (10):341-36

[11] Henry (2001)," Do stock market liberalisation cause Investment Booms", Journals of Financial economies, (58):301-334.

[12] Irving, J. (2001)," Africa's struggling Exchanges-Boost to economic Development of Costly Irrelevance", Africa Recovery, Abidjan.

[13] Kalu, I.K (2009)," Global Economic Meltdown" Issues that would reposition the Nigerian Capital market, http://allafrican.com/stones/2009/06290246.html

[14] Mohammad R and Salahuddin (2008)." The Determinant of Economic Growth in Pakistan" (1):1-22.
[15] Moore, Green and Murinde (2006a)," Financial Reforms and Stochastic policy Simulations: A flow of funds model", Journal of policy modeling.( 28): 319-333.

[16] Okereke Onyiuke Ndi (2008). 'A review of Market Performance in 2008 and outlook for 2009", the Nigerian stock Exchange. 2008 Edition.

[17] Rajni M and Mahendra R (2007), 'Measuring Stock market volatility in an emerging Economy", International Research Journals of finance and Economics, Issue ( 8):127-133

[18] Soyode A. and Oyedeji (2006): "The role of Capital Market in Economic development", Security market journal. 6

[19] Sule and Momoh (2009), "The roles of Stock Market Earnings on Nigeria per capita Income”, African journal of Accounting, Economics, Finance and Banking Research. (5):77-88.

[20] Victor Murinde (2009),"Global Financial crisis: Implications for Africa's financial system".

[21] Adam, J. A. \& Sanni, I. (2005). Stock Market Development and Nigeria's Economic Growth. Journal of Economics and Allied Fields, 2 (2), 116-132.

[22] Afees, A.S \& Kazeem, B.A (2010). The Stock Market and Economic Growth in Nigeria: An Empirical Investigation, Journal of Economic Theory, 4,65 - 70.

[23] Osaze B.E. (2009), 'Paradigm Shift Misplaced Concreteness and the Nigerian Financial System'. Inaugural lecture series.41. University of Benin. 40-41. 